\title{
The Radiomorphometric Indices of the Mandible as a Screening Method for Early Detection of Osteoporosis in Postmenopausal Women
} \author{
Boris Dželalija ${ }^{4,5}$ \\ ${ }^{1}$ Osijek Clinical Hospital Center, Department of Maxillofacial and Oral Surgery, Osijek, Croatia \\ ${ }^{2}$ Faculty of Dental Medicine and Health, Josip Juraj Strossmayer University of Osijek, Osijek, Croatia \\ ${ }^{3}$ Faculty of Medicine, Josip Juraj Strossmayer University of Osijek, Osijek, Croatia \\ ${ }^{4}$ Department of Infectious Disease, General Hospital Zadar, Zadar, Croatia \\ ${ }^{5}$ Department of Health Studies, University of Zadar, Zadar, Croatia
}

Bruno Popić1, Dubravka Holik², Vlatko Kopić ${ }^{1,3}$, Kristijan Dinjar ${ }^{1,3}$, Andrea Milostić-Srb², Danijela Nujiće ${ }^{2,3}$,

\begin{abstract}
A B S T R A C T
The aim of the study was to compare radiomorphometric indices measured on panoramic radiographs: mandibular cortical width (MCW), panoramic mandibular index (PMI) and mandibular cortical index (MCI) with the densitometric values of skeletons in postmenopausal women, as well as and to determine the possibilities of their use in screening for early detection of osteoporosis in risky populations. Radiomorphometric indices were measured on panoramic radiographs of 146 postmenopausal patients, mean age $66.3( \pm 9.7)$ years, mean menopausal age $16.3( \pm 10.6)$ years. By dual energy Xray absorptiometry (DXA) method were measured bone mineral density of the femur and the lumbar vertebrae (L1-L4). The Receiver Operating Characteristic (ROC) curve analysis was used to determine the changed densitometric finding, and to distinguish osteopenia and osteoporosis. The examinees with lower densitometric values had significantly lower $M C W(3.60 \mathrm{~mm})$ and PMI $(0.36 \mathrm{~mm})$ than those with regular densitometric values $(p<0.001)$. The most frequent finding in patients with osteopenia was C2 stage of erosion (69.50\%; $<<0.001)$, while the C3 stage of erosion (57.40\%; $<<0.001)$ was in osteoporosis patients. When differing the normal from the changed finding of densitometry the results were: MCW area under the curve (AUC) 0.862, sensitivity 92.04\%, specificity $75.76 \%$, resolution point $\leq 4.39$ ( $p<0.001)$; for PMI-AUC 0.874 , sensitivity $76.11 \%$, specificity $84.85 \%$, resolution point $\leq 0.41(p<0.001)$ and for $M C I-A U C 0.826$, sensitivity $87.6 \%$, specificity $69.7 \%$, resolution point $>1$ ( $p<0.001)$. For early detection of osteopenia and osteoporosis in postmenopausal women in everyday clinical practice, panoramic radiograph as a screening method can be of help.
\end{abstract}

Key words: panoramic radiograph, osteoporosis, postmenopause, radiomorphometric indices

\section{Introduction}

Osteoporosis is a systemic metabolic disease of the skeleton characterized by bone loss and disruption of internal bone tissue architecture, leading to increased bone fragility and fracture propensity ${ }^{1-6}$. According to WHO, osteoporosis occurs in $8-10 \%$ of the population and represents a significant public health and socio-economic problem ${ }^{7}$. The prevalence of osteoporosis increases exponentially with age ${ }^{8}$, and the prevalence of osteoporosis-induced fractures exceeds the overall prevalence of breast cancer, stroke, myocardial infarction, and heart failure ${ }^{9}$. Postmenopausal women have a higher risk of developing osteoporosis, and the most common cause is sudden estrogen reduction ${ }^{4-10}$. Accelerated bone loss and osteoporosis are also affected by harmful lifestyle habits such as smoking $^{11}$, alcohol consumption, and reduced physical activity ${ }^{12}$.

In the USA, $54 \%$ of postmenopausal women have osteopenia and $30 \%$ have osteoporosis, while in Brazil, $35-52 \%$ of women over 50 have reported bone $\operatorname{loss}^{13}$. An epidemiological study on osteoporosis that showed the magnitude of the problem in Croatia was conducted in several counties and was based on ultrasonic densitometry. Osteoporosis was found in $38.6 \%$ of respondents, and osteopenia in $45.4 \%$ of respondents, of which $95.2 \%$ were women, with an average age of 60 years ${ }^{14}$. The number of reported cases of osteoporosis and osteomalacia in primary health care in recent years has constantly increased and in 2004 by $0.70 \%$ compared to the total number of reported diseases ${ }^{15}$. Given that $50 \%$ of patients with oste- 
oporosis have no clinical symptoms of fracture, until the first spontaneous fracture or a fracture occurs with minimal trauma, it has been also called the silent disease ${ }^{16}$. Fractures most commonly occur in the thoracic and lumbar vertebrae, femoral neck and forearm, and 12-20\% of patients with a femoral fracture die within one year due to secondary causes, while $50 \%$ of survivors cannot resume a normal life activity ${ }^{17}$. Despite bone densitometry using the DXA method, which has become the gold stan$\operatorname{dard}^{18,19}$, there are still many at-risk individuals without a diagnosis and adequate treatment ${ }^{20}$. Several studies have confirmed that many women who have had an osteoporotic fracture had not been adequately treated for suspected osteoporosis ${ }^{21}$. BMD (bone mineral density) testing for at-risk individuals, especially postmenopausal women, is desirable but not available in many countries. Due to the above facts, it is sought to find other diagnostic and screening methods for early detection of osteoporosis and timely treatment ${ }^{22}$. Osteoporosis effects the mandible to the same extent as the rest of the skeleton, reduces bone mass, alters the mandibular structure, especially the lower mandibular cortex ${ }^{16}$. Based on radiomorphological indices and changes in the lower cortex of the mandible visible on panoramic radiographs, it is possible to identify women with undiagnosed osteoporosis and reference them to bone densitometry to determine the disease. The following overview radiomorphometric indices of the mandible were conspicuously used in the systematic review literature: MCI, MCW and PMI ${ }^{2,4,16,19}$. Elderly people, including postmenopausal women and women who are at risk for osteoporosis, will be more likely to attend regular dental and dental-surgical examinations (caries, periodontopathic, prosthetic rehabilitation) than to medical institutions for densitometry ${ }^{23}$. Hence, in the clinics of oral and maxillofacial surgery, as well as in any dental clinics many panoramic radiographs are made on an annual basis. About 10 million panoramic radiographs are recorded in Japan each year, and 17 million in the USA, and these panoramic radiographs may be used for screening individuals at increased risk of osteoporosis ${ }^{24,25}$. Panoramic radiographs can be easily accessed and represent non-invasive screening methods. That can help to diagnose osteoporosis and osteoporotic fractures, the morbidity and mortality of at-risk individuals and the elderly, and indirectly reduce treatment costs. The aim of this study was to compare radiomorphometric indices (MCW, PMI, MCI) with the densitometric values of skeletons in postmenopausal women, as well as and to determine the possibilities of their use in screening for early detection of osteoporosis in risky populations.

\section{Material and Methods}

The study was conducted at the Clinical Hospital Canter Osijek; at the Department of Mandibular and Mouth Surgery, the Department of Radiodiagnosis, and the Clinical Department of Endocrinology and Metabolic Diseases. The examinees participated in the study after signing an informed consent. The response rate was $97.3 \%(146 / 150)^{26}$.
The study was approved by the Ethics Committee of the Osijek Clinical Hospital and the Ethics Committee of the University of J. J. Strossmayer in Osijek (no. 2158-61-0711-23). A total of 150 postmenopausal examinees were enrolled in the study, with a life expectancy of between 40 and 90 years, which was referred to the Clinical Department of Mandibular and Mouth Surgery for dental casuistry. The prerequisite for inclusion in the study was menopause duration of at least one year. Exclusion criteria were existence of metabolic bone diseases, presence of malignancies with bone metastases, destructive lesions of jaw bone, use of drugs that affect bone metabolism, significant disorders of the kidneys or liver, hyperparathyroidism, multiple mixing, leukemia, Paget's disease and existing fractures in time of the densitometry. Of the 150 examinees, four were completely excluded from the study, because they did not perform the predicted examinations. Subjects who met the criteria for inclusion in the study were referred to the Department of Radiodiagnosis to have an orthopantomogram.

An apparatus (Planmeca OY; PM 2002 EC Proline, Finland) was used for the orthopantomogram or panoramic imaging. Medical X-ray orthochromatic film (SANIX ORTHO T1) manufactured by Fotokemika-nova Samobor, Croatia, was used. Female patients were positioned in such a way that the canter of the face followed the perpendicular devices, and the horizontal line (Frankfort plane) being parallel to the base. The obtained orthopantomograms were used to measure radiomorphometric indices using negatoscopes and digital moving scales ProfiScale Precision PS 7215 manufactured by Burg Watcher - Germany. The measurement of the width of the lower cortex of the mandible was done on both sides by drawing a vertical line in the projection of the mental foramen to the line parallel and tangential with the lower edge of the mandible, and the result obtained is the mean of the two measurements. The values of the measured mandibular indices were corrected for the magnification factor of the orthopantomogram (1,25x). Panoramic mandibular index represents the ratio between the thickness of the mandibular cortex and the distance between the lower edge of the mental foramen and the lower edge of the mandible ${ }^{27}$. The measurements of the panoramic index of the mandible were also done on both sides, and the result is the mean of the two measurements. An assessment of the morphological appearance of the mandibular lower cortex (MCI) was performed, on the examinees by classification into three groups (grade $\mathrm{C} 1-\mathrm{C} 3$ ) according to the criteria defined by Klemetti and associates ${ }^{30}$. Three stages are distinguished: C1- endoosteal margin of the cortex is even and sharp on both sides, C2- in which initial resorptive changes of the bone structure are visible, which are reflected in semilunar defects with cortical residues, and grade C3- with osteoporotic changes in the sense of distinct bone porosity with a large number of lacunas ${ }^{28}$. The readings of the orthopantomogram were used without insight into the findings of the densitometry performed on the same day as the orthopantomogram or at the latest a week from recording an orthopantomogram. Densitometry was performed at the Clinical Department of Endocri- 
nology and Metabolic Diseases of the Internal Clinic at the KBC Osijek by dual-energy x-ray absorption (DXA, double X-ray absorption) in the lumbar spine (L1-L4), and in the femoral neck using a device (DXA, Hologic QDR 4500 A/SL Delphi, Ohio, USA). Densitometry results are expressed as a T-score defined by the World Health Organization as the number of standard deviations above or below the average for a young person of the same sex. Regarding bone density values, normal bone density differs by T-score $>-1$, osteopenia T-score from -1 to -2.5 , and osteoporosis T-score $<-2.5$. After the densitometry was done, the examinees were referred for further diagnostic treatment, if it was a case of osteopenia or osteoporosis, with regards to the T-score.

\section{Statistical methods}

Descriptive statistical methods were used to describe the frequency distributions of the variables studied. All variables were tested for normality of distribution by the Kolmogorov-Smirnov test and, depending on the result, parametric or non-parametric methods were applied for their further processing. The mean values of continuous variables are expressed by the arithmetic mean and standard deviation for normally distributed variables and the median and range for variables that are not normally distributed. Student's T-test and Mann-Whitney test were used to determine differences between the two independent samples. The $\chi^{2}$ test and the Fisher exact test were used to determine differences between the proportions between the two independent samples ${ }^{29}$. Receiver Operat- ing Characteristic (ROC) analysis was applied to determine the optimal border values, area under the curve (AUC), specificity and sensitivity of the investigated parameters in the diagnosis of altered densitometric findings. Significance of differences determined by statistical testing was expressed at $p<0.05$. The originally written database programs and the Statistica for Windows 2010 statistical package (version 10.0, StatSoft Inc., Tulsa, OK) were used in the data processing.

\section{Results}

The study involved 146 patients, with an average age of $66.1( \pm 9.7)$ years, ranging from 47 to 88 years. The average duration of menopause was $16.3( \pm 10.6)$ years.

According to the findings of densitometry, the patients were initially divided into two groups: the group with normal findings (T-score $>-1$ ) and the group of patients with altered findings (osteopenia T-score from-1 to-2.5 and osteoporosis T-score<-2,5). There were 33 (22.60\%) patients with normal findings, and 113 (77.40\%) with altered. In the group of patients with altered densitometry findings, body mass index (BMI) values were significantly lower (T-test, $\mathrm{p}<0.001)$ (Table 1).

Mandibular indices were recorded on the orthopantomograms, with a significantly lower mandibular cortex width and lower values of panoramic mandibular index (Mann Whitney test, $\mathrm{p}<0.001$ ) in patients with altered findings (Table 2).

TABLE 1

DISTRIBUTION OF PATIENTS BY AGE, DURATION OF MENOPAUSE AND BMI IN RELATION TO DENSITOMETRY FINDINGS

\begin{tabular}{lcccccc}
\hline \multirow{2}{*}{ Parameters } & \multicolumn{4}{c}{ Densitometry } & \multirow{2}{*}{$\mathrm{p}^{\dagger}$} \\
\cline { 2 - 5 } & \multicolumn{3}{c}{ Normal findings } & \multicolumn{2}{c}{ Altered findings } & \\
\cline { 2 - 5 } & $\mathrm{N}$ & $\mathrm{MV}(\mathrm{SD}) *$ & $\mathrm{~N}$ & $\mathrm{MV}(\mathrm{SD})^{*}$ & \\
\hline Age (years) & 33 & $65.70(8.40)$ & 113 & $66.20(10.10)$ & 0.785 \\
Menopause duration (years) & 33 & $16.30(10.60)$ & 113 & $17.70(10.80)$ & 0.496 \\
Body mass index (BMI) (kg/m²) & 33 & $32.40(4.90)$ & 113 & $28.60(4.80)$ & $<0.001$ \\
\hline *Mean Value (Standard Deviation); $\dagger$ T-test & & & &
\end{tabular}

TABLE 2

MEAN VALUES OF MANDIBULAR INDICES ACCORDING TO DENSITOMETRY FINDINGS

\begin{tabular}{lllllll}
\hline \multirow{2}{*}{ Parameters } & \multicolumn{4}{c}{ Densitometry } & \\
\cline { 2 - 4 } & \multicolumn{3}{c}{ Normal finding } & Altered finding & $\mathrm{p}^{\dagger}$ \\
\cline { 2 - 5 } & $\mathrm{N}$ & $\mathrm{MV}(\mathrm{SD})^{*}$ & $\mathrm{~N}$ & $\mathrm{MV}(\mathrm{SD})^{*}$ & \\
\hline Mandibular cortical width $(\mathrm{MCW})(\mathrm{mm})$ & 33 & $4.60(0.61)$ & 113 & $3.60(0.70)$ & $<0.001$ \\
Panoramic mandibular index $(\mathrm{PMI})(\mathrm{mm})$ & 33 & $0.7(0.70)$ & 113 & $0.36(0.70)$ & $<0.001$ \\
\hline
\end{tabular}

*Mean Value (Standard Deviation); †Mann Whitney test 
Furthermore, a significant difference was observed for the width of the lower mandibular cortex (MCW) and the values of the panoramic index of the mandible (MPI) in patients with altered densitometry. In patients with osteoporosis the thickness of the mandibular cortex was lower and panoramic mandibular indices had lower values than in those with osteopenia (Mann Whitney test, $\mathrm{p}<0.001$ ) (Table 3).

Given the morphological appearance of the lower cortex of the mandible, most patients had erosion of a C2 degree, 69 (47.30\%), while the degree of C3 erosion had 40 (27.40\%) patients, and significantly more C3 findings were from the group with altered densitometric findings. The C2 degree erosion $(69.50 \%)$ was more common in osteopenic patients, while C3 degree (57.40\%) was more common in the group with an osteoporotic morphologic appearance of the lower mandible cortex $\left(\chi^{2}\right.$ test, $\left.\mathrm{p}<0.001\right)$ (Table 4$)$.
The ROC curves, based on specificity and sensitivity, assessed the values of individual parameters and the differences between the groups of the patients based on the densitometry findings (normal and altered findings). For each group, the cut-point was changed to obtain a ROC curve that objectively determined which value best separated the groups. In this study, as a diagnostic indicator of altered densitometry, the MCW (sensitivity=92.04, specificity=75.76; $\mathrm{p}<0.001)$, PMI (sensitivity=76.11, specificity $=84.85 ; \mathrm{p}<0.001)$ and MCI (sensitivity=87.60; specificity $=69.70 ; \mathrm{p}<0.001)$ to be significant (Table 5).

\section{Discussion}

The detection of osteoporosis in postmenopausal women should be one of the top priorities, if we wish to reduce the growing number of osteoporotic fractures that are a

TABLE 3

MEAN VALUES OF MANDIBULAR INDICES ACCORDING TO DENSITOMETRY FINDINGS IN A GROUP OF EXAMINEES WITH ALTERED FINDINGS

\begin{tabular}{|c|c|c|c|c|c|}
\hline \multirow{3}{*}{ Parameters } & \multicolumn{4}{|c|}{ Densitometry-altered finding } & \multirow{3}{*}{$\mathrm{p}^{\dagger}$} \\
\hline & \multicolumn{2}{|c|}{ Osteopenia } & \multicolumn{2}{|c|}{ Osteoporosis } & \\
\hline & $\mathrm{N}$ & $\mathrm{MV}(\mathrm{SD})^{*}$ & $\mathrm{~N}$ & $\mathrm{MV}(\mathrm{SD})^{*}$ & \\
\hline Mandibular cortical width (MCW) (mm) & 59 & $3.92(0.50)$ & 54 & $3.30(0.70)$ & $<0.001$ \\
\hline Panoramic mandibular index (PMI) $(\mathrm{mm})$ & 59 & $0.39(0.57)$ & 54 & $0.33(0.67)$ & $<0.001$ \\
\hline
\end{tabular}

*Mean Value (Standard Deviation); $†$ Mann Whitney test

TABLE 4

DIVISION OF SUBJECTS ACCORDING TO DENSITOMETRY FINDINGS AND DEGREE OF MORPHOLOGICAL APPEARANCE OF THE LOWER CORTEX OF THE MANDIBLE

\begin{tabular}{|c|c|c|c|c|c|}
\hline \multirow{3}{*}{$\begin{array}{l}\text { Morphological appearance } \\
\text { of the lower cortex of the } \\
\text { mandible (MCI) }\end{array}$} & \multicolumn{3}{|c|}{ Densitometry } & \multirow{3}{*}{$\begin{array}{l}\text { N (\%) } \\
\text { Total }\end{array}$} & \multirow{3}{*}{$\mathrm{p}^{*}$} \\
\hline & Normal finding & Osteopenia & Osteoporosis & & \\
\hline & $\mathrm{N}(\%)$ & $\mathrm{N}(\%)$ & $\mathrm{N}(\%)$ & & \\
\hline C1 degree & $23(69.70)$ & $10(16.90)$ & $4(7.40)$ & $37(25.30)$ & $<0.001$ \\
\hline $\mathrm{C} 2$ degree & $9(27.30)$ & $41(69.50)$ & $19(35.20)$ & $69(47.30)$ & \\
\hline C3 degree & $1(3.00)$ & $8(13.60)$ & $31(57.40)$ & $40(27.40)$ & \\
\hline Total & 33 (100) & $59(100)$ & $54(100)$ & $146(100)$ & \\
\hline
\end{tabular}

TABLE 5

ROC CURVE VALUES OF THE OBSERVED PARAMETERS

\begin{tabular}{|c|c|c|c|c|c|c|}
\hline & $\begin{array}{l}\text { Area under } \\
\text { the curve }\end{array}$ & $95 \% \mathrm{CI}$ & Sensitivity & Specificity & cut off & $\mathrm{p}$ \\
\hline Mandibular cortical width (MCW) (mm) & 0.862 & $0.795-0.913$ & 92.04 & 75.76 & $\leq 4.39$ & $<0.001$ \\
\hline Panoramic mandibular index (PMI) (mm) & 0.874 & $0.809-0.923$ & 76.11 & 84.85 & $\leq 0.41$ & $<0.001$ \\
\hline $\begin{array}{l}\text { Morphological appearance of the lower } \\
\text { cortex of the mandible (MCI) }\end{array}$ & 0.826 & $0.754-0.883$ & 87.60 & 69.70 & $>1$ & $<0.001$ \\
\hline
\end{tabular}


major socio-economic problem in developed countries. The most reliable diagnostic method for determining osteoporosis is the measurement of bone mineral density by DXA densitometry, but it is certainly not included in the appropriate screening methods. The prerequisites for a successful screening method for the population are wide availability, non-invasiveness and affordable method prices. The orthopantomogram meets the criteria for successful screening and have great potential in the diagnosis of osteoporosis. The results of our studies, involving 146 patients in the postmenopausal period, showed that, 33 (22.6\%) patients had normal densitometry findings, while in $133(77.4 \%)$ the densitometry test was altered towards lower values. Among the patients with altered densitometry, 59 (59.4\%) had osteopenia and 54 (40.6\%) had osteoporosis. In patients with altered densitometry findings, the values of body mass index $28.6(\mathrm{~kg} / \mathrm{m} 2)$ were significantly lower, compared to the body mass index $32.4(\mathrm{~kg} /$ $\mathrm{m} 2$ ) in patients with normal findings, and the results correlate with recent studies done among postmenopausal women in Saudi Arabia. ${ }^{16}$

Changes in osteoporotic patients also equally affect lower cortex of the mandible. ${ }^{4}$ Klemetti and associates were the first to determine an association between the MCW and the densitometric findings in menopausal wom$\mathrm{en}^{30}$. In our study examinees with normal densitometry findings had significantly wider lower cortex of the mandible $(4,60 \mathrm{~mm})$ compared to examinees with altered findings $(3.60 \mathrm{~mm})$. Based on the MCW, the cut point between examinees with normal and altered densitometry findings was $4.39 \mathrm{~mm}$ with a sensitivity of $92.04 \%$ and a specificity of $75.56 \%$. The area under the curve for the MCW index was 0.862 (95\% CI 0.795-0.913). The MCW index obtained in this study appropriately distinguishes the patients with altered findings from those with a normal densitometry finding, and the MCW index has proven to be an effective screening method for examinees suffering from or being prone to osteoporosis. White and associates in a study conducted in Japan stated that the $4,785 \mathrm{~mm}$ mandibular cortex thickness, $83 \%$ sensitivity and $43 \%$ specificity was an appropriate criterion for distinguishing normal from altered densitometry finding $\mathrm{s}^{31}$. The European multicentric study of osteoporosis as part of the OSTEODENT project, which included 671 postmenopausal women, concluded that examinees with thinner cortex MCW < $3.0 \mathrm{~mm}$ should be referred for further examination as part of the diagnosis of osteoporosis ${ }^{32}$. The results of this study are consistent with the results of recent studies that have confirmed significant differences between MCW indexes of normal and altered densitometry findings, thus highlighting its role in the diagnosis of osteoporosis ${ }^{19,23,33,34}$.

The Panoramic Mandibular Index is also a quantitative radiomorphometric index in the screening of patients with reduced bone mineral density. In this study, PMI values were found to be significantly different between patients with normal (PMI-0.47) and patients with altered densitometry findings (PMI-0.36). Assessing the diagnostic value of PMI by analyzing the ROC curve with a sensitivity of $76.11 \%$ and specificity of $84.85 \%$; and the area under the curve 0.874 (95\% CI 0.809-0.923), we concluded that PMI was an effective indicator for distinguishing the patients with normal from the ones with altered densitometry findings.

Several authors in their studies did not find a link between PMI and densitometry findings ${ }^{35,36}$.

Božić and Ihan-Hren in their study show a significant difference in MCW in patients with osteoporosis compared to women with normal densitometry findings, in contrast to PMI who did not show statistically significant among them $^{37}$. The results obtained by this study are in accordance with recent studies that highlight a significant difference in PMI in healthy, osteopenic and osteoporotic patients $\mathrm{s}^{4,19,38-40}$.

Mandibular cortical indices represent qualitative radiomorphometric indices based on the presence of erosion in the lower mandibular cortex. Women with eroded cortex of any degree have higher bone resorption and are at risk for low BMD. Analysis of the results obtained in this study revealed that $109(74.70 \%)$ patients had obvious cortical erosions, while 37 (25.30\%) patients had normal lower cortex finding. According to the densitometry findings, there are significant differences between the studied groups compared to the degree of erosion present. Patients with regular densitometry findings, $69.70 \%$ of them, typically had a $\mathrm{C} 1$ erosion rate, while in the osteopenic group, $69.50 \%$ had a C2 degree of erosion, and in the osteoporotic group, a $\mathrm{C} 3$ erosion rate of $57.40 \%$ of the patients.

MCI value had sensitivity $87.60 \%$, specificity $69.70 \%$, with area under curves of 0.826 (95\% CI $0.754-0.883)$. So, findings of this study indicate that MCI may be a diagnostic indicator for lower densitometric values, or rather lower bone density. Because MCI is a subjective assessment of the morphology of the mandibular lower cortex on panoramic radiographs, repeated interpretation between observations is crucial in evaluating the diagnostic use of this index in clinical practice.

In a European metacentric study, Horner and associates showed a limited value of MCI in the diagnosis of osteoporosis and suggested that only patients with eroded cortex would be triaged in dental offices about the high likelihood of osteoporosis ${ }^{41}$. Several authors did not confirm an important difference in MCI values in patients with normal densitometry findings and the ones with osteoporosis ${ }^{42,43}$. On contrary to the stated and in sync with the results from this study, several recent studies conducted in India, Korea, Brazil, and Saudi Arabia found that postmenopausal women with severe erosion of the lower cortex of the mandible have osteopenia or osteoporo$\operatorname{sis}^{8,13,38,44}$.

\section{Conclusion}

Analyzing the ROC curve of the diagnostic values of individual radiomorphometric indexes of the mandible, we conclude that the panoramic indices of the mandible (AUC value 0.874 ), the width of the lower cortex of the mandible (AUC value 0.862 ) and the mandibular cortical index 
(AUC value 0.826) are appropriate diagnostic indicators for distinguishing patients with normal densitometric findings from the ones with osteopenia and osteoporosis. Based on the results obtained, orthopantomograms and radiomorphometric indices as screening methods in everyday clinical practice may be helpful for early detection of osteopenia and osteoporosis in postmenopausal women. With personalized approach, dental doctors, maxillofacial and oral surgeons can play an important role in early diagnosis of osteopenia/osteoporosis and refer patients timely for further diagnostic analysis and treatment.

Funding: This research did not receive any specific grant from funding agencies in the public, commercial, or not-for-profit sectors.

Conflicts of Interest: The authors declare no conflict of interest

\section{R E F E R E N C E S}

1. ZORIČIĆ CVEK S, Medicina Fluminensis 44 (2008) 235. — 2. DAMILAKIS J, VLASIADIS K, Phys Med, 1 (2011) 39. doi: 10.1016/j. ejmp.2010.03.002 - 3. TAGUCHI A, Japanese Dental Science Review, 45 (2009) 109. doi:10.1016/j.jdsr.2009.05.001. — 4. NEMATI S, KAJAN ZD, SABERI BV, EFRANI MH, J Oral Maxilofac Radiol, 4 (2016) 23. doi: 10.4103/2321-3841.183820. — 5. KOLTE RA, KOLTE AP, POTEY AM, J Indian Soc Periodontol, 21 (2017) 461. doi: 10.4103/jisp.jisp_238_17. — 6. GRGIĆ O, KOVAČEV-ZAVIŠIĆ B, VELJOVIĆ T, NOVAKOVIĆ-PARO J, MARAVIĆ T, BAJKIN B, Clin Oral Investig, 21, (2017) 151. doi: 10.1007/ s00784-016-1767-6. - 7. ŠIMIĆ P, GILJEVIĆ Z, ŠIMUNIĆ V, VUKIČEVIĆ S, KORŠIĆ M, Arh Hig Rada Toksikol, 58, (2007) 55. doi: 10.2478/v10004-007-0009-3. - 8. MUNHOZ L, AOKI EM, CORTES ARG, DE FREITAS CF, ARITA ES, Gerodontology, 35 (2018) 101. doi: 10.1111/ger.12322. - 9. BARABA DEKANIĆ K, CRNČEVIĆ-ORLIĆ Ž, PERŠIĆ M, Medicina Fluminensis, 49 (2013) 4. - 10. KARASIK D, Hum Genet, 124 (2008) 349. doi 10.1007/s00439-008-0559-8. — 11. KANIS JA, JOHNELL O, ODEN A, JOHANSSON H, DE LAET C, EISMAN JA, FUJIWARA S, KROGER H, MCCLOSKEY EV, MELLSTROM D, MELTON LJ, POLS H, REEVE J, SILMAN A, TENENHOUSE A, Osteoporos Int, 16 (2005) 155. doi: 10.1007/s00439-008-0559-8. - 12. KANIS JA, JOHANSSON H, JOHNELL O, ODEN A, DE LAET C, EISMAN JA, POLS H, TENENHOUSE A, Osteoporos Int, 16 (2005) 737. doi: 10.1007/ s00198-004-1640-3. - 13. CARMO JZB, MEDEIROS SF, Rev Bras Ginecol Obstet, 39 (2017) 663. doi:10.1055/s-0037-1606622. - 14. KORŠIĆ M, Meducus 14 (2005) 237. - 15. CVIJETIĆ S, GRAZIO S, KAŠTELAN D, KORŠIĆ M, Liječnički Vjesnik, 128 (2006) 261. - 16. BALTO KA, GOMAA MM, FETEIH RM, ALAMOUDI NM, ELSAMANOUDY AZ, HASSANIEN MA, ARDAWI MSM, J Bone Metab, 25 (2018) 165. doi: 10.11005/ jbm.2018.25.3.165. - 17. VLASIADIS KZ, DAMILAKIS J, VELEGRAKIS GA, SKOUTERIS CA, FRAGOULI I, GOUMENOU A, MATALLIOTAKIS J, KOUMANTAKIS EE, Maturitas, 59 (2008) 226. doi: 10.1016/j. maturitas.2008.01.006. - 18. BAJORIA AA, ML A, KAMATH G, BABSHET M, PATIL P, SUKHIJA P, Open Dent J, 9 (2015) 303. doi: 10.2174/1874210601509010303. — 19. GROCHOLEWICZ K, JANISZEWSKA-OLSZOWSKA J, ANIKO-WŁODARCZYK M, ANIKO-WŁODARCZYK M, PREUSS O, TRYBEK G, SOBOLEWSKA E, LIPSKI M, BMC Oral Health, 18 (2018) 127. doi: 10.1186/s12903-0180593-4. - 20. DAMILAKIS J, MARIS TG, KARANTANAS AH, Eur Radiol, 17 (2007) 1591. doi: 10.1007/s00330-006-0511-z. - 21. MERTENS P, MACHANN J, MUELLER-BIERL B, STEIDLE G, BELLEMANN ME, SCHICK F, Med Phys, 35 (2008)1777. doi: 10.1118/1.2896079. — 22. FOLKESSON J, KRUG R, GOLDENSTEIN J, ISSEVER AS, FANG C, LINK TM, MAJUMDAR S, Med Phys, 36 (2009) 1267. doi: 10.1118/1.3097281. — 23. MURAMATSU C, HORIBA K, HAYASHI T, FUKUI T, HARA T, KATSUMATA A, FUJITA H, Int J Comput Assist Radiol Surg, 11 (2016) 2021. doi: 10.1007/s11548-016-1438-8. - 24. SHIMANO T, SUZUKI Y,
SASAKI T, Dent Radiol, 42 (2002) 9. - 25. AMERICAN DENTAL ASSOCIATION SURVEY CENTER, 2000 survey of dental practice: characteristics of dentists in private practice and their patients American Dental Association (2000). Available from: https://success.ada.org/en/practice-management/survey-of-dental-practice. - 26. KOLČIĆ I, BILOGLAV Z, Presječno istraživanje. In: KOLČIĆ I, VORKO-JOVIĆ A (Eds) Epidemiologija. (Medicinska naklada, Zagreb 2012). — 27. CAKUR B, SAHIN A, DAGISTAN S, ALTUN O, CAGLAYAN F, MILOGLU O, HARORLI A, J Int Med Res, 36 (2008) 792. doi: 10.1177/147323000803600422. — 28. KLEMETTI E, KOLMAKOW S, Dentomaxillofac Radiol, 26 (1997) 22. doi: 10.1038/sj.dmfr.4600203. - 29. PETRIE A, SABIN C, Medical Statistics at a Glance (Blackwell Science Ltd, London, 2000). - 30 KLEMETTI E, KOLMAKOV S, KROGER H, Scand J Dent Res, 102 (1994) 68. doi: 10.1111/j.1600-0722.1994.tb01156.x. - 31. WHITE SC, TAGUCHI A, KAO D, WU S, SERVICE SK, YOON D, SUEI Y, NAKAMOTO T, TANIMOTO K, Osteoporos Int, 16 (2005) 339. doi: 10.1007/s00198-004-16924. - 32. DEVLIN H, KARAYIANNI K, MITSEA A, JACOBS R, LINDH C, VAN DER STELT P, MARJANOVIC E, ADAMS J, PAVITT S, HORNER K, Oral Surg Oral Med Oral Pathol Oral Radiol Endod, 104 (2007) 821. doi: 10.1016/j.tripleo.2006.12.027. — 33. HASTAR E, YILMAZ HH, ORHAN H, Eur J Dent, 5 (2011) 60. — 34. OKABE S, MORIMOTO Y, ANSAI T, IZUMI YOSHIOKA I, TANAKA T, TAGUCHI A, KITO S, WAKASUGI-SATO N, ODA M, KUROIWA H, OHBA T, AWANO S, TAKATA Y, TAKEHARA T, Oral Surg Oral Med Oral Pathol Oral Radiol Endod, 106 (2008) 433. doi: 10.1016/j.tripleo.2007.09.013. — 35. MARANDI S, BAGHERPOUR A, IMANIMOGHADDAM M, HATEF M, HAGHIGHI A, J Dent, 7 (2010) 98. - 36. JOHARI KHATOONABAD M, AGHAMOHAMMADZADE N, TAGHILU H, ESMAEILI F, JABBARI KHAMNEI H, Iran J Radiol, 8 (2011) 23. - 37. BOŽIĆ M, IHAN HREN N, Journal of Cranio-Maxillo-Facial Surgery 41 (2013) 808. doi:10.1016/j. jcms.2013.01.033. - 38. JAGELAVICIENE E, KUBILIUS R, KRASAUSKIENE A, Medicina (Kaunas) 46 (2010) 95. - 39. SHAKEEL MK, DANIEL MJ, SRINIVASAN SV, KOLIYAN R, KUMAR JV, J Clin Diagn Res, 9 (2015) ZC12. doi: 10.7860/JCDR/2015/13606.6163. — 40. GOVINDRAJU P, CHANDRA P, J Clin Diagn Res, 8 (2014) 195. doi: 10.7860/ JCDR/2014/6844.4160. - 41. HORNER K, KARAYIANNI K, MITSEA A, BERKAS L, MASTORIS M, JACOBS R, LINDH C, VAN DER STELT P, MARJANOVIC E, ADAMS J, PAVITT S, DEVLIN H, J Clin Densitom, 10 (2007) 138. doi: 10.1016/j.jocd.2007.02.004.— 42. GRGIĆ O, KOVAČEV-ZAVIŠIĆ B, VELJOVIĆ T, NOVAKOVIĆ-PARO J, MARAVIĆ T, BAJKIN B, Clin Oral Investig, 21 (2017) 151. doi: 10.1007/s00784-0161767-6. - 43. JAGELAVIČIENĖ E, KRASAUSKIENĖ A, ŽALINKEVIČIUS R, VAITKEVIČIENE I, KUBILIUS R, Medicina (Kaunas) 52 (2016) 125. doi: 10.1016/j.medici.2016.02.005. — 44. KIM OS, SHIN MH, SONG IH, LIM IG, YOON SJ, KIM OJ, LEE YH, KIM YO, CHUNG HJ, Gerodontology, 33 (2016) 185. doi: 10.1111/ger.12134.

\section{Holik}

Josip Juraj Strossmayer University of Osijek, Faculty of Dental Medicine and Health, Crkvena ulica 21, 31000 Osijek, e-mail:dholik@mefos.hr 
RADIOMORFOMETRIJSKI INDEKSI MANDIBULE KAO METODA PROBIRA ZA RANO OTKRIVANJE OSTEOPOROZE KOD ŽENA U POSTMENOPAUZI

\section{S A Ž E T A K}

Cilj istraživanja bio je radiomorfometrijske indekse izmjerene na ortopantomogramu: debljina korteksa mandibule (engl. MCW-Mandibular core width), panoramski mandibularni indeks (engl. PMI Mandibular panoramic index) i mandibularni kortikalni indeks (engl. MCI-Mandibular cortical index) usporediti s denzitometrijom skeleta kod žena u postmenopauzi, te utvrditi mogućnosti njihove uporabe kao pouzdane metode probira za rano otkrivanje osteoporoze $u$ rizičnoj populaciji. Radiomorfometrijski indeksi izmjereni su na panoramskim snimkama kod 146 ispitanica u postmenopauzi, prosječne dobi $66,3( \pm 9,7)$ godina i prosječnog trajanja menopauze $16,3( \pm 10,6)$ godina. Svim ispitanicama izmjerena je mineralna gustoća kostiju u području vrata bedrene kosti i lumbalne kralježnice (L1-L4) metodom dvoenergetske apsorpciometrije X (engl. DXA-Dual energy X ray absorptiometry). Analiza ROC krivulje (eng. ROC-Receiver Operating Characteristic) korištena je u određivanju promijenjenog denzitometrijskog nalaza, te za razlučivanje osteopenije i osteoporoze. Ispitanice s nižim vrijednostima denzitometrije imale su značajno niže vrijednosti MCW-a $(3,60 \mathrm{~mm})$ i PMI-a $(0,36 \mathrm{~mm})$ od onih s pravilnim denzitometrijskim vrijednostima $(\mathrm{p}<0,001)$. Najčešći nalaz $u$ ispitanica s osteopenijom bio je stadij erozije C2 $(69,50 \%$; p <0,001), dok je kod ispitanica s osteoporozom značajno češći bio C3 stupanj erozije $(57,40 \% ; \mathrm{p}<0,001)$. Pri razlučivanju normalnog od promijenjenog nalaza denzitometrije dobiveni su slijedeći rezultati: MCW-AUC 0,862 , osjetljivost $92,04 \%$, specifičnost $75,76 \%$, točka razlučivanja $\leq 4,39(\mathrm{p}<0,001)$; za PMI-AUC 0,874 , osjetljivost $76,11 \%$, specifičnost $84,85 \%$, točka razlučivanja $\leq 0,41$ ( $p<0,001$ ); i za MCI-AUC 0,826 , osjetljivost $87,6 \%$, specifičnost $69,7 \%$, točka razlučivanja $>1(\mathrm{p}<0,001)$. Na temelju dobivenih rezultata zaključujemo da ortopantomogram može biti od velike pomoći u svakodnevnoj kliničkoj praksi kao metoda probira za rano otkrivanje osteopenije i osteoporoze kod žena u postmenopauzi. 
